\title{
Effect of Breeding Strategies to Increase Productivity of Indigenous Chicken in-situ in Bangladesh
}

\author{
F. Islam, S.C. Sarker ${ }^{1}$, M.N.M. Ibrahim ${ }^{2}$, A. M. Okeyo ${ }^{1}$, H. Jianlin ${ }^{2}$ \\ M.A.Hoque ${ }^{1}$ and A.K.F.H. Bhuiyan ${ }^{2^{\star}}$ \\ Department of Animal Breeding and Genetics \\ Bangladesh Agricultural University \\ Mymensingh, Bangladesh
}

\begin{abstract}
Performance of three generation $\left(G_{0}, G_{1}\right.$ and $\left.G_{2}\right)$ of indigenous chicken was evaluated to assess the effect of breeding strategies on the productivity. Data on age at sexual maturity (ASM), body weight at sexual maturity (BWM), body weight at one year of age (BWY), eggs per clutch (EGC), clutches per year (CLY), hatchability on set eggs basis (HAT) and survivability of baby chicks up to sexual maturity (SUR) were collected from a total of 1392 birds reared in four rural villages under traditional scavenging system during December 2010 to June 2013. The birds belong to three generations $\left(G_{0}, G_{1}\right.$ and $\left.G_{2}\right)$ and are from three breeding strategies $\left(B S_{I}\right.$ use of only pure and superior indigenous mature cocks, $\mathrm{BS}_{2}$ use of pure and superior indigenous mature cocks and mature hens and $B S_{3}$ use of existing or random indigenous cocks and hens). In $G_{2}$, the lowest ASM of male birds (156.56 \pm 3.39 days) was observed and the highest in $B S_{2}$, whereas in $B S_{3}$ high $B W M$ and $B W Y$ of male $(1200.00 \pm 19.99 ; 1779.63 \pm 27.20 \mathrm{gm})$ and female (994.48 \pm 10.86 ; $1350.38 \pm 14.46 \mathrm{gm})$ birds were observed in $B S_{2}$. However, in $G_{2}$ the highest EGC (14.97 \pm 0.20$), C L Y(4.53 \pm 0.05)$ and HAT $(89.79 \pm 0.96 \%)$ were observed in $B S_{1}$ but the highest SUR (51.15 $\pm 2.36 \%)$ was documented in BS. Present study revealed that use of superior Indigenous mature cocks alone and exercising cock rotation program can help to increase egg production, hatchability and decrease ASM of female birds of progressive generations in rural low input system. On the other hand, use of both superior Indigenous mature cocks and hens at a time at farmers end and exercising cock rotation program can help to improve body weight in rural low input system.
\end{abstract}

Keywords: Bangladesh, breeding strategies, indigenous chicken, productivity in- situ

\section{INTRODUCTION}

The contribution of the livestock and poultry sub sector in GDP at constant price is 2.5 percent in the financial year 2011-12 in Bangladesh. Though the share of the Livestock and poultry sub sector in GDP is small, but it has enormous contribution to meet the daily animal protein requirements for human consumption (MoFL, 2013). Islam et al. (2012) found the average number of chickens per household was 9.5, and the national share of commercial and family poultry in terms of egg production is probably almost equal and that of meat production is 60:40 (Bhuiyan, 2011). However, indigenous and local breeds share $90 \%$ of the total poultry population in developing countries (Besbes, 2009). According to the estimate of

\footnotetext{
International Livestock Research Institute (ILRI), Nairobi, Kenya

Professor, Dept. of Animal Breeding and Genetics, Bangladesh Agricultural University, Mymensingh 2202

Corresponding author: bhuiyanbau@gmail.com
} 
the Department of Livestock Services, the population of Livestock and Poultry were 53.21 million and 296.26 million, respectively but among poultry the number of chickens and ducks were 249.01 million and 47.25 million, respectively in 2012-13 (MoFL, 2013). On the other hand, according to MoFL (2013) per capita availability of milk, meat (beef, mutton and chicken) and eggs in Bangladesh were $91.03 \mathrm{ml} / \mathrm{head} / \mathrm{day}, 65.03 \mathrm{gm} / \mathrm{head} /$ day and 50.00 nos/head/year respectively where FAO recommended per capita requirement for the same commodities were $250 \mathrm{ml} / \mathrm{head} / \mathrm{day}, 120 \mathrm{gm} / \mathrm{head} / \mathrm{day}$ and $104.00 \mathrm{nos} / \mathrm{head} / \mathrm{year}$, respectively. This huge gap between demand and supply of animal protein as eggs and meat could be minimized by poultry keeping (Das et al., 2008).

FAO (2010) observed that among several ways like buying a cock to mate with the existing hens, record-based selection of the hens or buying high-yielding cross-bred chicks for meat or egg production, cock-improvement programme is the most common to influence the smallholder farmers for better production. Higher egg production, body weight gain and low mortality were observed in crossbred of RIR x Fayoumi (Sonali) among four different breed/breed combination under a semi scavenging production system but good management, availability of scavenging feed and rate of feed supplementation were the prerequisite of better performances (Zaman, 2003) though, high-yielding hens often show high levels of cannibalism and feather pecking in free ranging production systems (Sorensen, 2001). However, indigenous chicken perform better with respect to survivability, fertility and hatchability though, they have poor productivity under traditional or extensive production system. The low productivity does not encourage farmers to increase the present level of poultry operation (Huque and Haque 1990; Barua et al., 1998; Islam, 2006). In contrast, improved exotic chickens produce high number of eggs and amount of meat while they are not adapted to the adverse environmental conditions, such as high temperature, disease and shortage of feed (Ali et al., 2000; Islam and Nishibori, 2009). The FAO (2010) suggested that the low input/output smallholder system would continue to exist in many parts of the developing world, sustainable progress in productivity of 2 - 4 percent per year will be possible using local chickens.

The demand of indigenous chicken is sky rising and exotic hybrid are not performing up to expected standards in rural village conditions creating a big gap between demand and supply. Breeding efforts to improve Bangladesh chicken genetic resources have been undertaken mainly through an upgrading and/or crossbreeding programme under intensive and semiintensive production systems but with the indigenous Deshi chicken improvement and conservation programme at the smallholder village levels (in-situ) is yet to be tested (Bhuiyan et al. 2005). However, high demand of indigenous (Deshi) cockerels for the tenderness and special taste of their meat was observed (Ahmed and Ali, 2007). Barua and Howlider (1990) found non-descript Deshi chicken more acceptable to rural people as an important source of meat and egg because of low nutritional demand and high resistance to diseases and heat stress shown by Deshi chicken. Moreover, Chowdhury (2012) observed that indigenous chicken were popular among rural, peri-urban and urban people and were usually sold at double the price or even more of the commercial strains of broilers. Nevertheless, under traditional husbandry system indigenous chicken found better matched to the economy of poor livestock keepers in Bangladesh (Bhuiyan, 2011). Hence, local chicken production was an established component of the rural economy and necessity for its development is obvious (Kperegbeyi et al., 2009). The objective of this study was to assess the effect of three breeding strategies on the changes in productivity of indigenous chicken of progressive generations in the low input production system in Bangladesh. 


\section{METHODOLOGY}

\section{Location of study}

Data were collected from four villages namely, Rangtia $\left(25^{\circ} 22^{\prime} \mathrm{N} \& 90^{\circ} 09^{\prime} \mathrm{E}\right)$, Shalchura $\left(25^{\circ} 21^{\prime} \mathrm{N} \& 90^{\circ} 08^{\prime} \mathrm{E}\right)$, Dudhnoi $\left(25^{\circ} 18^{\prime} \mathrm{N} \& 90^{\circ} 09^{\prime} \mathrm{E}\right)$ and Bangaon $\left(25^{\circ} 16^{\prime} \mathrm{N} \& 90^{\circ} 09^{\prime} \mathrm{E}\right)$ of Jhenaigati upazila under Sherpur district in Bangladesh. Global Positioning System (etrex, VENTURE HC, GARMIN) was used to mark the locations of villages.

\section{Feeding, vaccination and de-worming of chicken}

Birds were raised under traditional scavenging system with feed supplementation (40 to 50 $\mathrm{gm} / \mathrm{hen}$ or cock). Feed ingredients such as rice kura, rice polish, rice bran, broken rice, wheat, kitchen waste, boiled rice with or without water and table salt separately or in a mixer were includes in this diet. Regular vaccinations against Newcastle and Fowl pox diseases were done as per manufacturer's instruction and de-worming was also done in a regular interval of 4 months period.

\section{Alternate breeding strategies}

\section{Breeding strategy one $\left(\mathrm{BS}_{1}\right)$}

Superior mature cocks were collected from the indigenous chicken gene pool of Bangladesh Livestock Research Institute (BLRI). BLRI cocks possessed a standard body weight of 1500 to $1900 \mathrm{gm}$, at age 210 days to 224 days, also they were free from disease deformations, regularly vaccinated and de-wormed, alert and responsive. BLRI birds were comparatively better performing than the locally found indigenous cocks. Forty households (HHs) were included in this study and a total of 481 birds of generation zero $\left(G_{0}\right)$, one $\left(G_{1}\right)$ and two $\left(G_{2}\right)$ were individually evaluated. Only pure and superior indigenous mature cocks were distributed among HHs and successive generations of chicks were produced. The superior cocks distributed to each village were rotated in $G_{1}$ and $G_{2}$ among the households to avoid the full sib and half sib mating.

\section{Breeding strategy two $\left(\mathrm{BS}_{2}\right)$}

Pure and superior indigenous mature cocks and mature hens were distributed and successive generations of chicks were produced. Forty HHs were taken under this study and a total of 488 birds of $G_{0}, G_{1}$ and $G_{2}$ were individually evaluated. Criteria which were used to select superior indigenous mature hens were: appearance, alert and responsive, disease conditions pelvis width (above $20 \mathrm{~mm}$ ), age (not over 210 days) and body weight (not less than 800 $\mathrm{gm}$ ). The criteria of superior cocks were same as described under $\mathrm{BS}_{1}$. Cocks were rotated in $\mathrm{G}_{1}$ and $\mathrm{G}_{2}$ among the households to avoid the full sib and half sib mating.

\section{Breeding strategy three $\left(\mathrm{BS}_{3}\right)$}

Existing or traditional system of breeding of indigenous chicken (mature cocks and mature hens roam together under scavenging system) available at farmers' houses were used and successive generations of progeny were produced. Forty HHs were considered in this study and a total of 423 birds of $\mathrm{G}_{0}, \mathrm{G}_{1}$ and $\mathrm{G}_{2}$ were individually evaluated. 


\section{Traits recorded}

ASM: The age on which a male bird took part in mating was considered as the ASM of male bird while the age on which a female bird laid her first egg was calculated as the ASM of female bird.

BWM and BWY: Live BWM and BWY were taken using a $5 \mathrm{~kg}$ weighing balance (CAMRY, CHINA.).

EGC: Number of eggs laid by a hen at a single start until becomes broody with or without gap for one or two days was calculated as eggs per clutch.

CLY: Mean clutch intervals from three consecutive clutches of egg production were used to calculate the number of CLY. Clutch interval between two clutches is a period of days from start of lay for one clutch to the start of lay for the immediate next clutch.

The formula used in calculating CLY is given in Equation 1.

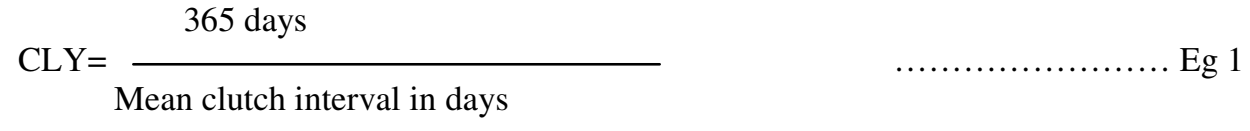

HAT and SUR: HAT and SUR were calculated using Equations 2 and 3.

\begin{tabular}{|c|c|c|}
\hline \multirow{2}{*}{ HAT $=$} & Number of day old chicks hatched out & \multirow{2}{*}{$\times 100$} \\
\hline & Number of eggs set & \\
\hline & Number of birds survived up to ASM & \\
\hline
\end{tabular}

\section{Data collection and analysis}

Birds were individually identified using leg and wing bands. Data were collected with the help of an in-depth data collection format developed by GEF Asia project by door to door visit. Farmers were given orientation on the use of data collection sheet for egg laying and hatching information, and periodical visits were made to verify the collected information. Body weight and other information were collected by direct visit to farmer's house. SAS (2006) software was used to calculate descriptive statistics and Duncan Multiple Range Test (DMRT) results on ASM, BWM, BWY, EGC, CLY, HAT and SUR. The least squares means were obtained in SAS GLM using the following generalized linear model:

$Y_{i j k}=\mu+B_{i}+G_{j}+e_{i j k}$

Where, $\mathrm{Y}_{\mathrm{ijk}}=$ Dependent variables (ASM, BWM, BWY, EGC, CLY, HAT and SUR)

$\mu=$ Overall population mean for any of the said traits;

$B_{i}=$ Effect of $i^{\text {th }}$ breeding strategy (where $i=1,2$ and 3 ),

$\mathrm{G}_{\mathrm{j}}=$ Effect of $\mathrm{j}^{\text {th }}$ generation (where $\mathrm{j}=0,1$ and 2)

$\mathrm{e}_{\mathrm{ijk}}=$ Random residual error associated with $\mathrm{Y}_{\mathrm{ijk}}$ observation. 


\section{RESULTS AND DISCUSSION}

Under $\mathrm{BS}_{1}$ and $\mathrm{BS}_{2}$, ASM of female birds decreased from $\mathrm{G}_{1}$ to $\mathrm{G}_{2}$ but in $\mathrm{BS}_{3}$, ASM increased from $\mathrm{G}_{1}$ to $\mathrm{G}_{2}$ (Table 1). Moreover, in $\mathrm{G}_{2}$, ASM were lower in $\mathrm{BS}_{1}(168.50 \pm 1.12)$ than $\mathrm{BS}_{2}$ $(169.63 \pm 1.05)$. This result indicated that $\mathrm{BS}_{1}$ could have contributed more to early maturity of female birds of progressive generations under traditional scavenging production system at rural villages than $\mathrm{BS}_{2}$ and $\mathrm{BS}_{3}$.

Table 1. Age at sexual maturity (ASM) of Indigenous chicken in different generations under different breeding strategies (number of observations are given in the parenthesis)

\begin{tabular}{|c|c|c|c|c|c|}
\hline Sex & & $\mathbf{G}_{\mathbf{0}}$ & $\mathbf{G}_{1}$ & $\mathbf{G}_{2}$ & LS \\
\hline \multirow[t]{4}{*}{ Male } & $\mathrm{BS}_{1}$ & $164.32 \pm 1.17(38)$ & $160.00 \pm 2.22(32)$ & $159.60 \pm 2.81(25)$ & NS \\
\hline & $\mathrm{BS}_{2}$ & $163.76^{\mathrm{b}} \pm 1.14$ & $160.82^{\mathrm{a}} \pm 1.93$ & $160.63^{\mathrm{a}} \pm 2.51(27)$ & * \\
\hline & $\mathrm{BS}_{3}$ & $168.57^{\mathrm{c}} \pm 1.85$ & $156.44^{\mathrm{a}} \pm 2.95(27)$ & $156.56^{\mathrm{b}} \pm 3.39(18)$ & $* *$ \\
\hline & $\mathrm{LS}$ & NS & NS & NS & \\
\hline \multirow[t]{4}{*}{ Female } & $\mathrm{BS}_{1}$ & $188.19^{\mathrm{c}} \pm 0.59(156)$ & $169.69^{\mathrm{b}} \pm 1.15(127)$ & $168.50^{\mathrm{a}} \pm 1.12$ & $* * *$ \\
\hline & $\mathrm{BS}_{2}$ & $187.56^{\mathrm{c}} \pm 0.59(156)$ & $170.53^{\mathrm{b}} \pm 0.99(129)$ & $169.63^{\mathrm{a}} \pm 1.05(105)$ & $* * *$ \\
\hline & $\mathrm{BS}_{3}$ & $188.64^{\mathrm{c}} \pm 0.66$ & $169.13^{\mathrm{a}} \pm 1.21$ & $169.53^{\mathrm{b}} \pm 1.56(74)$ & $* * *$ \\
\hline & LS & NS & NS & NS & \\
\hline
\end{tabular}

Breeding strategy did not effect on ASM of male and female birds significantly in $\mathrm{G}_{0}, \mathrm{G}_{1}$ and $\mathrm{G}_{2}$ (Table 1). The observation of ASM (156.44 \pm 2.95 to $188.19 \pm 0.59$ days) at present study were very close to Kalita et al. (2009) (160.63 \pm 4.61 to $177.27 \pm 4.88$ days) but lower than Bhuiyan et al. (2005) (175 to 234 days) and Benabdeljelil et al. (2001) (29 weeks / 203 days) in semi scavenging condition. In $\mathrm{BS}_{2}$, ASM of male birds between $\mathrm{G}_{1}$ and $\mathrm{G}_{2}$ did not differ significantly. Though, ASM of male birds was the lowest in $\mathrm{BS}_{3}$ in $\mathrm{G}_{2}$, it was even lower in $\mathrm{G}_{1}$. Therefore, it is remaining unclear whether $\mathrm{BS}_{3}$ has shortened the ASM of male in progressive generations or not. The findings of the present study indicated that breeding strategy did not contribute significantly to ASM of male birds in progressive generations.

Breeding strategy (BS) affect significantly on BWM of female birds (Table 2) in $\mathrm{G}_{0}$ and $\mathrm{G}_{2}$ but not on those in $\mathrm{G}_{1}$. However, $\mathrm{BWM}$ of female birds were higher in $\mathrm{BS}_{2}$ than those reported by Kalita et al. (2009) (body weight of indigenous chickens $740.00 \pm 11.67 \mathrm{gm}$ to $862.25 \pm 17.31 \mathrm{gm}$ at the age of 5 months) but lower than those reported by Daikwo et al. (2011) $(1.05 \pm 0.02 \mathrm{~kg})$. The BWM of female birds were higher in $\mathrm{BS}_{2}$ than $\mathrm{BS}_{1}$ and $\mathrm{BS}_{3}$ in both $G_{1}$ and $G_{2}$ Hence, the present observation indicated that $B_{2}$ could contribute more to increase BWM of female birds of progressive generations at in-situ under traditional scavenging production system at rural villages than $\mathrm{BS}_{1}$ and $\mathrm{BS}_{3}$. 
Table 2. Body weight at sexual maturity (BWM) of Indigenous chicken in different generations under different breeding strategies (number of observations are given in the parenthesis)

\begin{tabular}{llllll}
\hline Sex & & $\mathbf{G}_{\mathbf{0}}$ & $\mathbf{G}_{\mathbf{1}}$ & $\mathbf{G}_{\mathbf{2}}$ & LS \\
\hline \multirow{4}{*}{ Male } & $\mathrm{BS}_{1}$ & $1427.63^{\mathrm{ax}} \pm 9.90(38)$ & $1009.06^{\mathrm{cy}} \pm 24.11(32)$ & $1089.06^{\mathrm{by}} \pm 23.29(25)$ & $* * *$ \\
& $\mathrm{BS}_{2}$ & $1413.16^{\mathrm{y}} \pm 7.68(38)$ & $1159.39^{\mathrm{x}} \pm 29.07(33)$ & $1200.00^{\mathrm{x}} \pm 19.99(27)$ & $\mathrm{NS}$ \\
& $\mathrm{BS}_{3}$ & $788.11^{\mathrm{z}} \pm 13.07(37)$ & $765.56^{\mathrm{z}} \pm 15.31(27)$ & $767.22^{\mathrm{z}} \pm 21.54(18)$ & $\mathrm{NS}$ \\
& $\mathrm{LS}$ & $* * *$ & $* * *$ & $* * *$ & \\
& $\mathrm{BS}_{1}$ & $839.62^{\mathrm{y}} \pm 11.04(156)$ & $883.86 \pm 8.70(127)$ & $918.83^{\mathrm{y}} \pm 9.22(103)$ & $\mathrm{NS}$ \\
Female & $\mathrm{BS}_{2}$ & $909.42^{\mathrm{x}} \pm 9.39(156)$ & $942.71 \pm 9.46(129)$ & $994.48^{\mathrm{x}} \pm 10.86(105)$ & $\mathrm{NS}$ \\
& $\mathrm{BS}_{3}$ & $807.79^{\mathrm{z}} \pm 9.33(154)$ & $805.40 \pm 12.33(113)$ & $818.78^{\mathrm{z}} \pm 16.57(74)$ & $\mathrm{NS}$ \\
& $\mathrm{LS}$ & $* * *$ & $\mathrm{NS}$ & $* * *$ & \\
\hline
\end{tabular}

Note: LS=Level of significance. NS= Not Significant and ${ }^{* * *}$ significance at lower than $0.1 \%$, ${ }^{\text {xyz }}$ Means with the different superscripts differed significantly within the column $(\mathrm{P}<0.05)$. ${ }^{\mathrm{abc}}$ Means with the different superscripts differed significantly within the row $(\mathrm{P}<0.05)$.

Breeding strategy (BS) affected significantly on BWM of male birds in $\mathrm{G}_{0}, \mathrm{G}_{1}$ and $\mathrm{G}_{2}$ (Table 2). $\mathrm{BWM}$ of male birds in $\mathrm{BS}_{1}(1427.63 \pm 9.90 \mathrm{gm})$ and $\mathrm{BS}_{2}(1413.16 \pm 7.68 \mathrm{gm})$ were higher than $\mathrm{BS}_{3}$ in $\mathrm{G}_{0}$ and also the value reported by Daikwo et al. (2011) $(1.32 \pm 0.02 \mathrm{~kg})$. The BWM were higher in $\mathrm{BS}_{2}$ in $\mathrm{G}_{1}$ than $\mathrm{BS}_{1}$ and $\mathrm{BS}_{3}$ and similarly the $\mathrm{BWM}$ were higher in $\mathrm{BS}_{2}$ $(1200.00 \pm 19.99 \mathrm{gm})$ in $\mathrm{G}_{2}$ than $\mathrm{BS}_{1}$ and $\mathrm{BS}_{3}$. The results indicated that $\mathrm{BS}_{2}$ could have contributed more to increase $\mathrm{BWM}$ of male birds in progressive generations under traditional scavenging production system at rural villages than those contributed by $\mathrm{BS}_{1}$ and $\mathrm{BS}_{3}$.

Breeding strategy affected significantly of BWY of female birds in $G_{0}, G_{1}$ and $G_{2}$ (Table 3). In $G_{1} B W Y$ of female birds were higher in $B_{2}$ than $B_{1}$ and $B_{3}$. Similarly, in $G_{2} B W Y$ were higher in $\mathrm{BS}_{2}(1350.38 \pm 14.46 \mathrm{gm})$ than $\mathrm{BS}_{1}$ and $\mathrm{BS}_{3}$. It might be indicative that $\mathrm{BS}_{2}$ could contribute more to increase BWY of female birds of progressive generations under traditional scavenging production system at rural villages than those contribute by $\mathrm{BS}_{1}$ and $\mathrm{BS}_{3}$. 
Table 3. Body weight at one year of age (BWY) of male and female birds in different generations under different breeding strategies (number of observations are given in the parenthesis)

\begin{tabular}{llllll}
\hline Sex & & $\mathbf{G}_{\mathbf{0}}$ & $\mathbf{G}_{\mathbf{1}}$ & $\mathbf{G}_{\mathbf{2}}$ & $\mathbf{L S}$ \\
\hline Male & $\mathrm{BS}_{1}$ & $2061.32^{\mathrm{ay}} \pm 23.90(38)$ & $1618.44^{\mathrm{cy}} \pm 31.35(32)$ & $1706.00^{\mathrm{by}} \pm 26.67(25)$ & $* * *$ \\
& $\mathrm{BS}_{2}$ & $2161.58^{\mathrm{ax}} \pm 21.59(38)$ & $1691.21^{\mathrm{cx}} \pm 26.33(33)$ & $1779.63^{\mathrm{bx}} \pm 27.20(27)$ & $* * *$ \\
& $\mathrm{BS}_{3}$ & $1020.81^{\mathrm{z}} \pm 17.42(37)$ & $1075.56^{\mathrm{z}} \pm 21.88(27)$ & $1099.44^{\mathrm{z}} \pm 35.06(18)$ & $\mathrm{NS}$ \\
& $\mathrm{LS}$ & $* * *$ & $* * *$ & $* * *$ & \\
Female & $\mathrm{BS}_{1}$ & $1073.91^{\mathrm{cy}} \pm 13.67(156)$ & $1189.13^{\mathrm{by}} \pm 10.92(127)$ & $1239.03^{\mathrm{ay}} \pm 12.33$ & $*$ \\
& & & $(103)$ & \\
& $\mathrm{BS}_{2}$ & $1245.96^{\mathrm{x}} \pm 12.56(156)$ & $1308.68^{\mathrm{x}} \pm 14.70(129)$ & $1350.38^{\mathrm{x}} \pm 14.46(105)$ & $\mathrm{NS}$ \\
& $\mathrm{BS}_{3}$ & $1002.79^{\mathrm{z}} \pm 9.76(154)$ & $1040.53^{\mathrm{z}} \pm 11.51(113)$ & $1049.05^{\mathrm{c}} \pm 16.45(74)$ & $\mathrm{NS}$ \\
& $\mathrm{LS}$ & $* * *$ & $* * *$ & $* * *$ & \\
\hline
\end{tabular}

Note: LS=Level of significance, NS= Not Significant, *significance at 1.1 to $5 \%$ and $* * *$ significance at lower than $0.1 \%$. ${ }^{\mathrm{xy}}$ Means with the different superscripts differed significantly within the column $(\mathrm{P}<0.05) .{ }^{\mathrm{abc}}$ Means with the different superscripts differed significantly within the row $(\mathrm{P}<0.05)$.

Breeding strategy (BS) affected significantly on BWY of male birds in $\mathrm{G}_{0}, \mathrm{G}_{1}$ and $\mathrm{G}$ (Table 3). BWY of male birds increased from $G_{1}$ to $G_{2}$ in both $B S_{1}$ and $B_{2}$ while there were no significant changes observed in $\mathrm{BS}_{3}$. $\mathrm{BWY}$ in $\mathrm{G}_{0}$, in $\mathrm{BS}_{1}$ and $\mathrm{BS}_{2}$ were close to the live weight of cocks as reported by Portas et al. (2010). However, BWY of male birds were the highest in $\mathrm{BS}_{2}$ in $\mathrm{G}_{1}$, and similarly $\mathrm{BWY}$ were the highest in $\mathrm{BS}_{2}(1779.63 \pm 27.20 \mathrm{gm})$ in $\mathrm{G}_{2}$. This result indicates that $\mathrm{BS}_{2}$ could contribute more to $\mathrm{BWY}$ of male birds of progressive generations under traditional scavenging production system at rural villages than $\mathrm{BS}_{1}$ and $\mathrm{BS}_{3}$.

Breeding strategy (BS) affected significantly on EGC (Table 4) only in $\mathrm{G}_{1}$ and $\mathrm{G}_{2 . .}$ EGC in $\mathrm{BS}_{3}(12.02 \pm 0.11$ to12.25 \pm 0.17$)$ were similar to the observation made by Portas et al. (2010) (10-12 eggs/clutches) and Benabdeljelil et al. (2001) (13.5 eggs/ clutch) However, EGC in $\mathrm{BS}_{1}$ and $\mathrm{BS}_{2}$ in $\mathrm{G}_{1}$ and $\mathrm{G}_{2}$ were in line with the observations made by Islam et al. (2012) (15.7 \pm 1.24 eggs/clutch) and Shahjahan et al. (2011) (15.45 eggs/clutch). EGC were higher in $\mathrm{BS}_{1}$ than $\mathrm{BS}_{2}$ and $\mathrm{BS}_{3}$ both in $\mathrm{G}_{1}$ and $\mathrm{G}_{2}$. This observation clearly indicates that $\mathrm{BS}_{1}$ contribute heavily to increase EGC of progressive generations under traditional scavenging production system at rural villages than $\mathrm{BS}_{2}$ and $\mathrm{BS}_{3}$.

Table 4. Eggs per clutch (EGC) and clutches per year (CLY) of Indigenous chicken in different generations under different breeding strategies (number of observations are given in the parenthesis)

\begin{tabular}{crllll}
\hline Trait & \multicolumn{1}{c}{$\mathbf{G}_{\mathbf{0}}$} & \multicolumn{1}{c}{$\mathbf{G}_{\mathbf{1}}$} & \multicolumn{1}{c}{$\mathbf{G}_{\mathbf{2}}$} & \multicolumn{1}{c}{ LS } \\
\hline EGC & $\mathrm{BS}_{1}$ & $11.96^{\mathrm{c}} \pm 0.10(156)$ & $14.39^{\mathrm{bx}} \pm 0.17(127)$ & $14.97^{\mathrm{ax}} \pm 0.20(103)$ & $* * *$ \\
& $\mathrm{BS}_{2}$ & $12.17^{\mathrm{c}} \pm 0.10(156)$ & $14.26^{\mathrm{by}} \pm 0.16(129)$ & $14.86^{\mathrm{ay}} \pm 0.22(105)$ & $* * *$ \\
& $\mathrm{BS}_{3}$ & $12.02 \pm 0.11(154)$ & $12.09^{\mathrm{z}} \pm 0.13(113)$ & $12.25^{\mathrm{z}} \pm 0.17(74)$ & $\mathrm{NS}$ \\
& $\mathrm{LS}$ & $\mathrm{NS}$ & $* * *$ & $* * *$ & \\
$\mathrm{CLY}$ & $\mathrm{BS}_{1}$ & $4.56^{\mathrm{x}} \pm 0.08(156)$ & $4.52 \pm 0.05(129)$ & $4.53^{\mathrm{x}} \pm 0.05(103)$ & $\mathrm{NS}$ \\
& $\mathrm{BS}_{2} 4.38^{\mathrm{y}} \pm 0.08(156)$ & $4.44 \pm 0.05(129)$ & $4.46^{\mathrm{y}} \pm 0.05(105)$ & $\mathrm{NS}$ \\
& $\mathrm{BS}_{3} 4.12^{\mathrm{z}} \pm 0.07(154)$ & $4.17 \pm 0.06(113)$ & $4.14^{\mathrm{z}} \pm 0.07(74)$ & $\mathrm{NS}$ \\
& $\mathrm{LS}$ & $* *$ & $\mathrm{NS}$ & $*$ &
\end{tabular}

Note: $\mathrm{LS}=$ Level of significance, $\mathrm{NS}=$ Not Significant, *significance at 1.1 to $5 \%$, **significance at 0.1 to $1 \%$ and $* * *$ significance at lower than $0.1 \%$. ${ }^{\mathrm{xyz}}$ Means with the different superscripts differed significantly within the column $(\mathrm{P}<0.05)$. ${ }^{\mathrm{abc}}$ Means with the different superscripts differed significantly within the row $\left.\mathrm{P}<0.05\right)$. 
Clutches per year differed significantly with BS (Table 4) in $\mathrm{G}_{0}$ and $\mathrm{G}_{2}$ but did not change in $\mathrm{G}_{1}$. However, CLY did not change significantly among generations. The CLY observed in the present study were higher than that was reported by Islam et al. (2012) $(3.4 \pm 0.25$ clutches/year) and Shahjahan et al. (2011) (3.50 clutches/year). Present study showed that CLY were the highest in $\mathrm{BS}_{1}$. Moreover, the highest CLY in $\mathrm{BS}_{1}$ were observed $(4.53 \pm 0.05)$ in $\mathrm{G}_{2}$. The present results suggest that $\mathrm{BS}_{1}$ could have contributed to increase CLY of progressive generations under traditional scavenging production system at rural villages.

Hatchability (HAT) has got affected significantly by BS (Table 5) within generation among generations. The value of $\mathrm{HAT}$ in $\mathrm{BS}_{3}$ observed in the present study $(79.99 \pm 1.08 \%$ to $82.01 \pm 1.42 \%)$ were similar to Kalita et al. (2009) and (70 -81\%) Portas et al. (2010). However, the HAT observed in $\mathrm{BS}_{1}$ and $\mathrm{BS}_{2}$ were higher than Azharul et al. (2005) (on fertile egg basis hatchability; $87 \%$ ). However, HAT was higher in $\mathrm{BS}_{1}$ than $\mathrm{BS}_{2}$ and $\mathrm{BS}_{3}$ both in $G_{1}$ and $G_{2}$. According to the present results, it could be suggested that $B_{1}$ could have contributed more than $\mathrm{BS}_{1}$ and $\mathrm{BS}_{2}$ to increase $\mathrm{HAT}$ of progressive generations under traditional scavenging production system at rural villages.

Table 5. Hatchability on set egg basis in percent (HAT) and survivability (SUR) of baby chicks up to age of sexual maturity of Indigenous chicken in different generations under different breeding strategies (number of observations are given in the parenthesis)

\begin{tabular}{llllll}
\hline Trait & \multicolumn{1}{c}{$\mathbf{G}_{\mathbf{0}}$} & \multicolumn{1}{c}{$\mathbf{G}_{\mathbf{1}}$} & \multicolumn{1}{c}{$\mathbf{G}_{\mathbf{2}}$} & \multicolumn{1}{c}{ LS } \\
\hline HAT & $\mathrm{BS}_{1}$ & $87.31^{\mathrm{y}} \pm 0.57(156)$ & $89.98^{\mathrm{x}} \pm 0.70(127)$ & $89.79^{\mathrm{x}} \pm 0.96(103)$ & $\mathrm{NS}$ \\
& $\mathrm{BS}_{2}$ & $87.98^{\mathrm{x}} \pm 0.61(156)$ & $89.35^{\mathrm{y}} \pm 0.65(129)$ & $89.01^{\mathrm{y}} \pm 0.71(105)$ & $\mathrm{NS}$ \\
& $\mathrm{BS}_{3}$ & $79.99^{\mathrm{z}} \pm 1.08(154)$ & $80.70^{\mathrm{z}} \pm 1.19(113)$ & $82.01^{\mathrm{z}} \pm 1.42(74)$ & $\mathrm{NS}$ \\
& $\mathrm{LS}$ & $* *$ & $* *$ & $* * *$ & \\
Trait & & $\mathrm{G}_{1}$ & $\mathrm{G}_{2}$ & $\mathrm{G}_{3}$ & $\mathrm{LS}$ \\
SUR & $\mathrm{BS}_{1}$ & $49.36 \pm 1.37(156)$ & $48.41 \pm 1.23(127)$ & $48.93 \pm 1.14(103)$ & $\mathrm{NS}$ \\
& $\mathrm{BS}_{2}$ & $46.55 \pm 1.36(156)$ & $48.89 \pm 1.52(129)$ & $49.48 \pm 1.54(105)$ & $\mathrm{NS}$ \\
& $\mathrm{BS}_{3}$ & $49.01 \pm 2.11(154)$ & $48.58 \pm 1.73(113)$ & $51.15 \pm 2.36(74)$ & $\mathrm{NS}$ \\
& $\mathrm{LS}$ & $\mathrm{NS}$ & $\mathrm{NS}$ & $\mathrm{NS}$ & \\
\hline
\end{tabular}

Note: NS $=$ Not Significant, ${ }^{* *}$ significance at 0.1 to $1 \%$ and ${ }^{* * *}$ significance at lower than $0.1 \% . ~ . ~{ }^{\mathrm{xy}} \mathrm{Means}$ with the different superscripts differed significantly within the column $(\mathrm{P}<0.05)$.

Neither the breeding strategies nor the generations affected SUR significantly (Table 5). However, SUR $(46.55 \pm 1.36$ to $51.15 \pm 2.36 \%)$ observed in the present study were higher than those observed by Portas et al. (2010) (10\% to $13 \%$ up to age of eight weeks) and Choprakarn (2007) (30\% up to one year of age in semi scavenging condition). Results of the present study suggest that BS could not contribute to the survivability of chicks.

\section{CONCLUSIONS}

Present study revealed that use of superior Indigenous mature cocks alone and exercising cock rotation program could help to increase eggs per clutch, clutches per year, hatchability and decrease age at sexual maturity of female birds in progressive generations in rural low input system. On the other hand, use of both superior indigenous mature cocks and hens at a time and exercising cock rotation program could help to improve body weight at sexual 
maturity and body weight at one year of age of Indigenous scavenging chicken of Bangladesh.

\section{ACKNOLEDGEMENT}

Authors are thankful to the UNEP-GEF-ILRI-FAnGR Asia Project for supporting the research facility of this study.

\section{REFERENCES}

Ali, K.O., Katule, A.M. and Syrstad, O. (2000). Genotype $\times$ Environment interaction for growing chickens: Comparison of four genetic groups on two rearing systems under tropical condition. ACTA AGR SCAND A-AN., 50, 65 - 71.

Ahmed, S.T. and Ali, M.A. (2007). Performance of Synthetic, Desi, Synthetic x Desi and Synthetic $x$ Star cross brown chicken at marketing. Proceedings of the $5^{\text {th }}$ International Poultry Show and Seminar, World's Poultry Science Association, Bangladesh Branch, p. 18 -25 .

Azharul, I., Ranvig, M.H. and Howlider, M.A.R. (2005). Incubating capacity of broody hens and chick performance in Bangladesh. LRRD., 17, 1 - 10.

Barry (1998). Broodiness and broody hens. Available at http://www.feathersite.com/Poultry/BRKBroody.html.

Barua, A. and Howlider, M.A.R. (1990). Prospect of native chickens in Bangladesh. Poult. Adviser., 23, 57 - 61.

Barua, A., Howlider, M.A.R. and Yoshimura, Y. (1998). Indigenous naked neck fowl of Bangladesh. World's Poult. Sci. J., 54, 279 - 286.

Benabdeljelil, K., Arfaoui, T. and Johnston, P. (2001). Traditional poultry farming in Morocco. Proceedings of the 10th Conference of the Association of Institutions for Tropical Veterinary Medicine, Copenhagen.

Besbes, B. (2009). Genotype evaluation and breeding of poultry for performance under suboptimal village conditions. World's Poult. Sci. J., 65, 260 - 271.

Bhuiyan, A.K.F.H. (2011) Implementation of National Livestock Development Policy (2007) and National Poultry Development Policy (2008): Impact on smallholder livestock rearers. Keynote paper presented at the South Asia Pro Poor Livestock Policy Programme (SAPPLP)-BRAC workshop held at BRAC Centre Inn, Dhaka.

Bhuiyan, A.K.F.H., Bhuiyan, M.S.A. and Deb, G.K. (2005). Indigenous chicken genetic resources in Bangladesh: Current status and future outlook. AGRI., 36, 73 - 84.

Choprakarn, K. (2007). Status of Thai Indigenous Chickens: current and future. Faculty of Agriculture, Ubon Ratchathaini University, Thailand. 
Chowdhury, S.D. (2012). Keynote Paper on Indigenous poultry: Need for policy intervention and sustainable approaches to higher productivity. Proceedings of a Seminar, Animal Husbandry Faculty Gallery, Bangladesh Agricultural University, Mymensingh, p. 8-20.

Daikwo, I.S., Okpe, A.A. and Ocheja, J.O. (2011). Phenotypic characterizations of local chickens in Dekina. Int. J. Poult. Sci., 6, 444 - 447.

Das, S.C., Chowdhury, S.D., Khatun, M.A., Nishibori, M., Isobe, N and Yoshimura, Y. (2008). Poultry production profile and expected future projection in Bangladesh. World's Poult. Sci. J., 64, 99 - 118.

FAO (2010). Chicken genetic resources used in smallholder production systems and opportunities for their development, by P. Sorensen. FAO Smallholder Poultry Production Paper No. 5. Rome.

Huque, Q.M.E. and Haque. M.E. (1990). The onset of lay in indigenous hens following hatching of chicks. Poult. Adviser., 12, 57 - 60.

Islam, M.A. (2006). Comparative egg production and egg quality of indigenous full feathered and naked neck chicken at hot-humid climate. Bang. J. Anim. Sci 35, 99 - 105.

Islam, M.A. and Nishibori, M. (2009). Indigenous naked neck chickens: A valuable genetic resources for Bangladesh. World's Poult. Sci. J., 65, 125 - 138.

Islam, F., Sarker, S.C., Bhuiyan, A.K.F.H., Akteruzzaman, M., Bett, R.C., Baltenweck, I., Poole, J., Ibrahim, M.N.M. and Okeyo, A.M. (2012). The status of indigenous chicken farming \& options for improvement in Bangladesh. Proceedings of a Seminar, Animal Husbandry Faculty Gallery, Bangladesh Agricultural University, Mymensingh, p. 21.

Kalita, N., Gawande, S.S. and Barua, N. (2009). Production and reproduction performance of indigenous chicken of Assam under rural condition. IJPS., 44(2).

Kperegbeyi, J.I., Meye, J.A. and Ogboi, E. (2009). Local chicken production: strategy of household poultry development in coastal regions of Niger Delta, Nigeria. Afr. J. Gen. Agric., 5(1).

MoFL (2013). Department of Livestock Services, Ministry of Fisheries and Livestock (MoFL), Government of the People's Republic of Bangladesh, Dhaka.

Portas, O.O., William, O.O., Samwel, O.O., Gerald, M., Edward, O., Maurice, O.O. and Rubin, F.A. (2010). Assessing the productivity of indigenous chickens in an extensive management system in southern Nyanza, Kenya. Trop. Anim. Health Prod., 42, 283 - 288.

SAS (2006). SAS Institute Inc., SAS Campus Drive, Cary, North Carolina 27513, USA.

Shajahan, M., Amin, M.R. and Bhuiyan, A.K.F.H. (2011). Diversity in performance of indigenous chicken in some selected areas of Bangladesh in-situ. Proceedings of $9^{\text {th }}$ Asia Pacific Poultry Conference, the World's Poultry Science Association Taiwan.

Smith, A.J. (1990). Poultry-Tropical Agriculturist series. CTA, Macmillan Publishers, London, p 179 - 184. 
Sorensen, P. (2001). Breeding strategies in poultry for genetic adaptation to the organic environment. Proceedings of 4th Workshop of the Network for Animal Health in Organic Agriculture, Wageningen, 51 - 61.

Zaman, M.A.U. (2003). Egg production performance of different breed/breed combinations of chicken in semi scavenging system under PLDP. M. Sc. Thesis, Department of Animal Breeding and Genetics, Danish Insatiate of Agricultural Sciences, Research Centre Foulum, P.O. Box 50, DK-8830 Tjele Denmark. 